\title{
Development of Ecosystems of Innovative Entrepreneurship in the Global Dimension
}

\author{
INNA RIEPINA \\ Department of Business Economics and Entrepreneurship, \\ Kyiv National Economic University named after Vadym Hetman \\ NATALiIa YakusheVA \\ Department of Business Economics and Entrepreneurship, \\ Kyiv National Economic University named after Vadym Hetman
}

\begin{abstract}
Each country seeks rapid economic development and welfare of the population in need of improving its innovation sector, which is a prerequisite for success and sustainable competitive position in the global market.The development of innovative entrepreneurship is a topical issue in every country. Its development depends on the successfully formed ecosystem of innovative entrepreneurship. The article considers the models of innovation, which are the basis for the creation of a country's economy of innovative type, namely: the model of the triple spiral of innovation, the model of the quadruple spiral of innovation,
\end{abstract}


the model of the fivefold spiral of innovation. The value of the article is the consideration of the successful construction of models of innovation systems in the world, which gives an opportunity to form a model of the ecosystem of innovative entrepreneurship for Ukraine.

Keywords: ecosystem of innovative entrepreneurship, model of the triple spiral of innovations, model of the fourfold spiral of innovations, model of the fivefold spiral of innovations, elements of the ecosystem of innovative entrepreneurship, innovative growth

JEL Classification Codes: F63, L26, M21, O33, O57, P51

\section{Introduction:}

In the context of globalisation and development of the digital economy, Ukraine's transition to an innovative model of economic growth is an urgent issue. The purpose of the article is to consider the models of innovation systems of the world and the formation of a successful model of the ecosystem of innovative entrepreneurship for Ukraine. An important prerequisite for the transition to innovative growth is the effective development of innovative entrepreneurship. Therefore, the study of the development and effective formation of its components is a topical issue today.

\section{Research results}

The main components of innovative entrepreneurship and the formation of its ecosystem are venture capital, high-tech products, support infrastructure (business incubators, business accelerators, technology parks, innovation centres (hubs), resource conservation policy, intellectualisation of production. The relationship and interaction of the components of innovative entrepreneurship constitute its ecosystem. Therefore, for the successful development of the innovation economy it is necessary to form an effective and successful ecosystem of innovative entrepreneurship. To better understand and see the essence of building this model of economy, we propose onsidering the experience and components of ecosystems in different countries of the world.

In our opinion, it is expedient to consider the ecosystem of innovative entrepreneurship of the United Arab Emirates. The country is building a stable and diversified economy that supports strategies such as the UAE's National Innovation Strategy and Abu Dhabi Economic Vision 2030. A successful model of the ecosystem of innovative entrepreneurship has been built in the UAE, which contributes to the effective 
development of start-ups. In the UAE ecosystem of innovative entrepreneurship, the main players are the government, industry, and academia. Start-ups are the driving force behind the UAE's innovative entrepreneurship ecosystem. The elements of support for the ecosystem of innovative entrepreneurship are the following:

1. infrastructure;

2. network and relationships;

3. available market;

4. incubators and accelerators;

5. technical skills;

6. advanced skills;

7. financing;

8. investment culture;

9. $R \& D$;

10. social culture and thinking;

11. training and education;

12. human capital;

13. legislation (Aamna Ali Aljarwan et al., 2019).

For a better vision of the UAE innovation entrepreneurship ecosystem, we present the results of the study in Figure 1.

The United Arab Emirates is building and developing a successful ecosystem of innovative entrepreneurship, of which the ways of effective development are:

1. Encouragement of the government to work by establishing non-profit joint laboratories.

2. Improving the performance of the industry by allocating a percentage of its procurement to the government to acquire start-ups.

3. Reduction of legal costs for the creation of new innovative enterprises.

4. Involvement of academic students in start-ups for internships.

5. Promoting the development of entrepreneurship by the academies by creating permanent acceleration programmes for senior design projects that would encourage students to continue working on their projects.

6. Formation of own incubators at universities.

7. Creation of equity funds in high-tech industries, which are funds designed exclusively for investment in specific technologies (Aamna Ali Aljarwan et al., 2019). Thus, the ecosystem of innovative entrepreneurship in the United Arab Emirates has a centralised model and is based on the significant influence of the government, which is an effective driver of innovative entrepreneurship. The country uses the triple helix model ecosystem for the formation and functioning of the innovation business ecosystem, the main participants of which are the government, academia and industry. The government develops strategies for the private sector and industry 
that promote innovative entrepreneurship. The UAE government uses the top-down approach to shape and strengthen the ecosystem, encouraging ecosystem participants to cooperate and support each other by providing incentives. The weakest relations exist between the industry and academia, as these relations are insufficiently stimulated. Different cities have different philosophies of economic development: some focus on the internal growth of start-ups, others - on the outsourcing of global talent for accelerated growth. This philosophy contributes to the diversification of the overall UAE economy.

Figure 1. Ecosystem of innovative entrepreneurship in the UAE

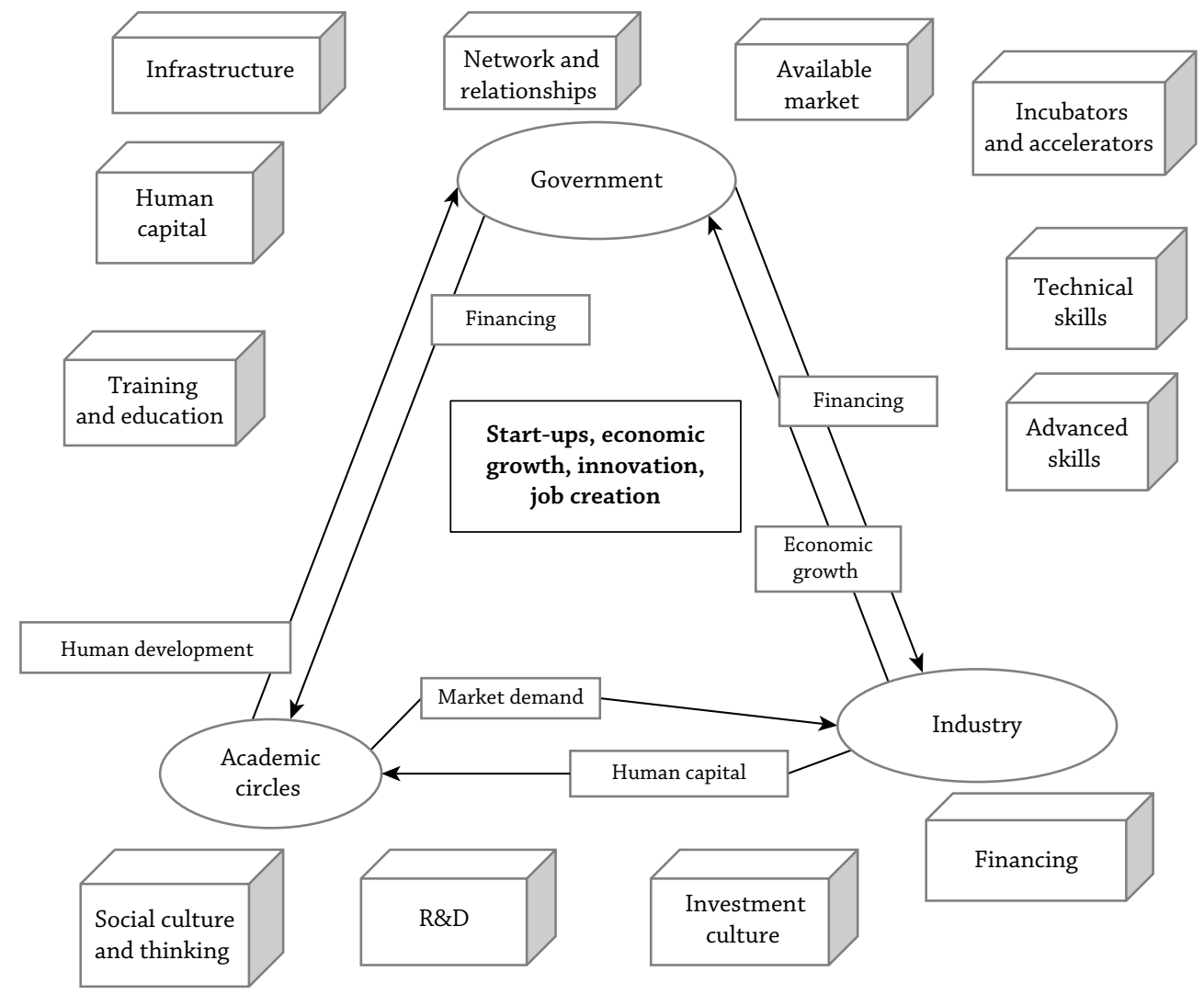

Source: own work based on Aamna Ali Aljarwan et al. (2019).

To study the experience of other participants in the world market, we believe that it is necessary to consider the formation and development of the ecosystem of innovative entrepreneurship in China. This country aims to become an innovation centre by 2025. China's innovation ecosystem is based on the triple helix model, with 
the government, universities and the industry playing a key role in the innovation ecosystem. It should be noted that the government plays an important role in the development of the ecosystem of innovative entrepreneurship and R\&D funding. The results of research on the model of the ecosystem of innovative entrepreneurship in China will be presented in Table 1.

Table 1. China's innovative entrepreneurship ecosystem

\begin{tabular}{|l|l|l|}
\hline \multicolumn{1}{|c|}{ Space of knowledge } & \multicolumn{1}{c|}{ Innovative space } & \multicolumn{1}{c|}{ Consensus space } \\
\hline $\begin{array}{l}\text { 1. Public R\&D funding for } \\
\text { the industry, universities and } \\
\text { public research institutes }\end{array}$ & $\begin{array}{l}\text { 1. Tax deductions, a special } \\
\text { innovation fund }\end{array}$ & $\begin{array}{l}\text { 1. Universities and industry } \\
\text { act in coordination with the } \\
\text { government }\end{array}$ \\
\hline $\begin{array}{l}\text { 2. Publications and patents for } \\
\text { inventions }\end{array}$ & $\begin{array}{l}\text { 2. Legislation in the field of } \\
\text { intellectual property }\end{array}$ & $\begin{array}{l}\text { 2. Implementation of the } \\
\text { "Made in China" Strategy until } \\
\text { 2025. }\end{array}$ \\
\hline $\begin{array}{l}\text { 3. Legislation in the field of } \\
\text { intellectual property }\end{array}$ & $\begin{array}{l}\text { 3. University enterprises } \\
\text { (UREs) }\end{array}$ & 3. The "Belt \& Road" Initiative \\
\hline & $\begin{array}{l}\text { 4. Demonstration zones } \\
\text { of innovations, business } \\
\text { incubators, infrastructure }\end{array}$ & $\begin{array}{l}\text { 4. 5-year plans, national } \\
\text { congresses }\end{array}$ \\
\hline
\end{tabular}

Source: own work based on Akpinar and Qi (2020)..

The Chinese government supports innovation in the following ways:

1. policy to encourage innovation;

2. finding opportunities to support innovation;

3. development of schemes and initiatives for international cooperation;

4. creation of regulations and financial incentives that support innovation;

5. providing conditions to support research and innovation;

6. introduction of incentives for the formation of a successful ecosystem of innovative entrepreneurship in China.

From the above it can be concluded that in China the government is a major player in the innovation market and plays a key role in shaping the ecosystem of innovative entrepreneurship. In China, as in the UAE, the ecosystem model is centralised, using a top-down approach. The government develops a strategy for innovative development and provides public funding for R\&D.

The considered countries have successful developments in the field of innovation, using the triple helix model for the development and formation of the ecosystem of innovative entrepreneurship. In modern conditions of innovation development, ecosystem models of innovative entrepreneurship are changing and improving. Each country creates its own ecosystem, which ensures its successful development. The development and improvement of spiral models of innovation is shown in Figure 2. 
Figure 2. Spiral models of innovation and interweaving of subsystems

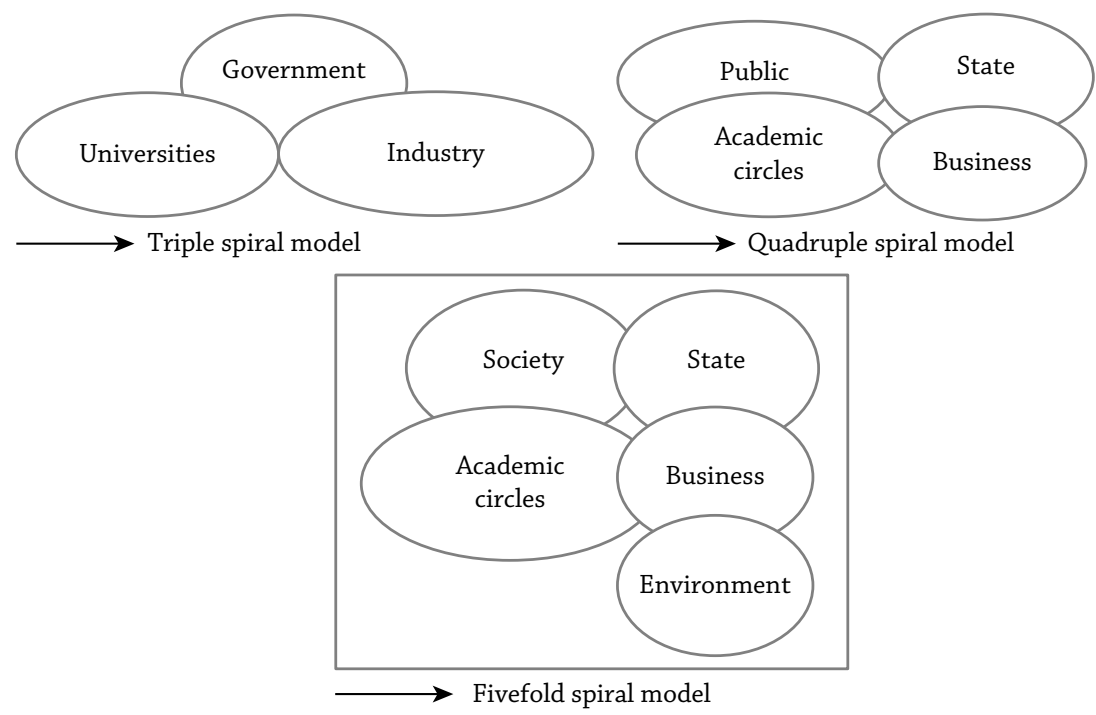

Source: own work based on König at al. (2020).

Thus, the model of the triple spiral of interaction between the governmentuniversities-industry is the basis for the development of innovation in a country, which is of great importance in the development of society from industrial to knowledge society. It is very widespread among researchers in the field of innovation and entrepreneurship. In our opinion, the model of the triple spiral in the process of society development has improved and given impetus to the creation of four- and fivefold models of innovation in different countries. In particular, in European countries, projects such as Construye 2020+ and Horizon 2020 implement and develop the fivefold spiral of innovation model, which develops and works closely in the following areas: political environment, education and science, economics, culture and environment (ecological sphere). In February 2020, the Directorate-General for Research and Innovation hosted a conference entitled A Sustainable Innovation Ecosystem for the Future of Europe, held in Brussels. The aim of the conference was to strengthen cooperation between the EU institutions and its citizens, to enrich and inform the strategic planning of Horizon Europe. The report of the conference contains recommendations on innovation policy and innovation ecosystems. The report brings together the ideas, suggestions and key findings of a series of consultations with European innovation stakeholders. These included universities, communities, investors, corporations, local, regional and national authorities, and national ministries responsible for innovation policy. The Innovation Ecosystems 
Unit of the European Innovation Council Working Group organised eight seminars with each stakeholder:

1. start-ups and start-up associations;

2. industry and corporations;

3. investors (private venture capital, corporate venture capital and business angels);

4. universities and scientific and technical organisations;

5. cities;

6. regions;

7. National Innovation Agencies;

8. ministries.

In its proposal for the next Horizon Europe research and innovation framework, which sets EU priorities and R\&D funding from 2021 to 2027, for the first time the European Commission has included a section on European innovation ecosystems with a proposed budget of $€ 500$ million (Barrera, 2020).

For a better study of the models of ecosystems of innovative entrepreneurship, we find it appropriate to consider the experience of the United States. This country uses a decentralised model in the formation of the ecosystem of innovative entrepreneurship. The elements of the US ecosystem are: universities, government, corporations, start-up accelerators, venture firms and funds, private investors, various funds, entrepreneurs, mentors, and the media. The ecosystem of innovative US entrepreneurship is illustrated in Figure 3 for clarity.

Figure 3. The ecosystem of innovative entrepreneurship in the United States

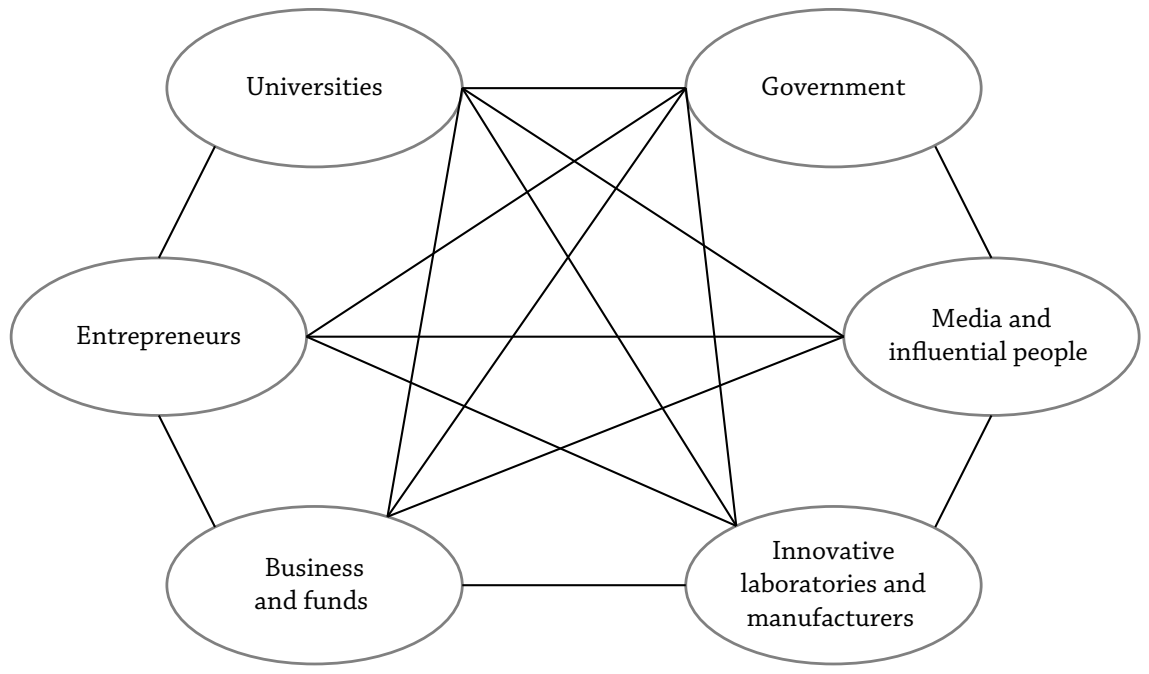

Source: own work based on Millard (2018). 
For the successful development and functioning of the ecosystem of innovative entrepreneurship in the United States the following measures are applied:

1. ensuring transparency in the functioning of all participants in the ecosystem;

2. conducting training of highly qualified personnel;

3. assisting corporations in identifying and implementing important technologies for innovation;

4. assisting investors in finding the best companies and projects to invest;

5. implementing measures to create an ecosystem of innovative entrepreneurship that will effectively move the country's economy forward.

Summarising the above, we can conclude that the ecosystem of innovative entrepreneurship in the United States is based on the principle of partnership between the state and the private sector, which uses the bottom-up approach. The interaction between universities and the industry is significant and increases profits in the field of innovation, stimulates the development of knowledge. Particular attention is paid to academic entrepreneurship and the development of start-ups, which connects universities with the industry. Therefore, innovative US entrepreneurship is developing successfully.

We consider it expedient to take into account the experience of Poland in creating an ecosystem of innovative entrepreneurship, which is growing rapidly and gaining strength. According to a published World Bank report, Poland was recognised as one of the most attractive ecosystems for start-ups in the world, ranking higher than Australia and the United Kingdom. This gives Poland a great opportunity to take a key place in Central and Eastern Europe in the market of start-ups, attracting ambitious entrepreneurs to an active community (Yomy, 2018). Administrative conditions and tax legislation are important factors that facilitate the transformation of a business idea into a start-up. Poland has a highly developed potential for the successful development of innovative entrepreneurship, such as legal regulation, finance, human capital, social capital, and developed institutional environment, which allows Poland to develop rapidly in the field of innovation. According to the World Bank rating, cities such as Warsaw, Cracow, and Poznan are the best choice to start your own business (Yomy, 2018). Important levers to facilitate the creation and conduct of business in Poland are tax benefits for foreign investors, the availability of special economic zones for entrepreneurs to receive numerous incentives. The country is attractive for investment and has a rapidly developing economy. The innovation sector is developing especially fast. In particular, the Polish divisions of BNP Paribas Securities Services were the first to introduce robotics in their work, they took this step for business development. Robotics is just one of many aspects that Polish business representatives can teach their foreign partners (Yomy, 2018). Poland has a high potential for the development of start-ups. It is estimated that 
by 2023 the added value created by start-ups may amount to 2.2 billion zlotys, and the number of jobs created may reach 50 thousand (Yomy, 2018). The country has a highly developed venture capital market. The Polish Development Fund - Polski Fundusz Rozwoju (PFR) - provides funding for the development of Polish startups. Most start-ups are self-funded. Poland exports its innovative products abroad to countries such as the United States, Great Britain and Germany. Innovative projects in Poland are supported by the National Research and Development Centre. Entrepreneurs can apply for financial support. The ecosystem of innovative entrepreneurship in Poland develops in accordance with market needs and begins with the formation of clusters, networks, the triple helix model, quadruple helix model, which in turn leads to the formation of a successful ecosystem of innovative entrepreneurship. Progress is achieved as a result of the development and productive interaction of participants in the innovation system, forming a complex ecosystem of innovative entrepreneurship. The development of the ecosystem model of innovative entrepreneurship in Poland is shown in Figure 4.

Figure 4. Development of the ecosystem of innovative entrepreneurship in Poland

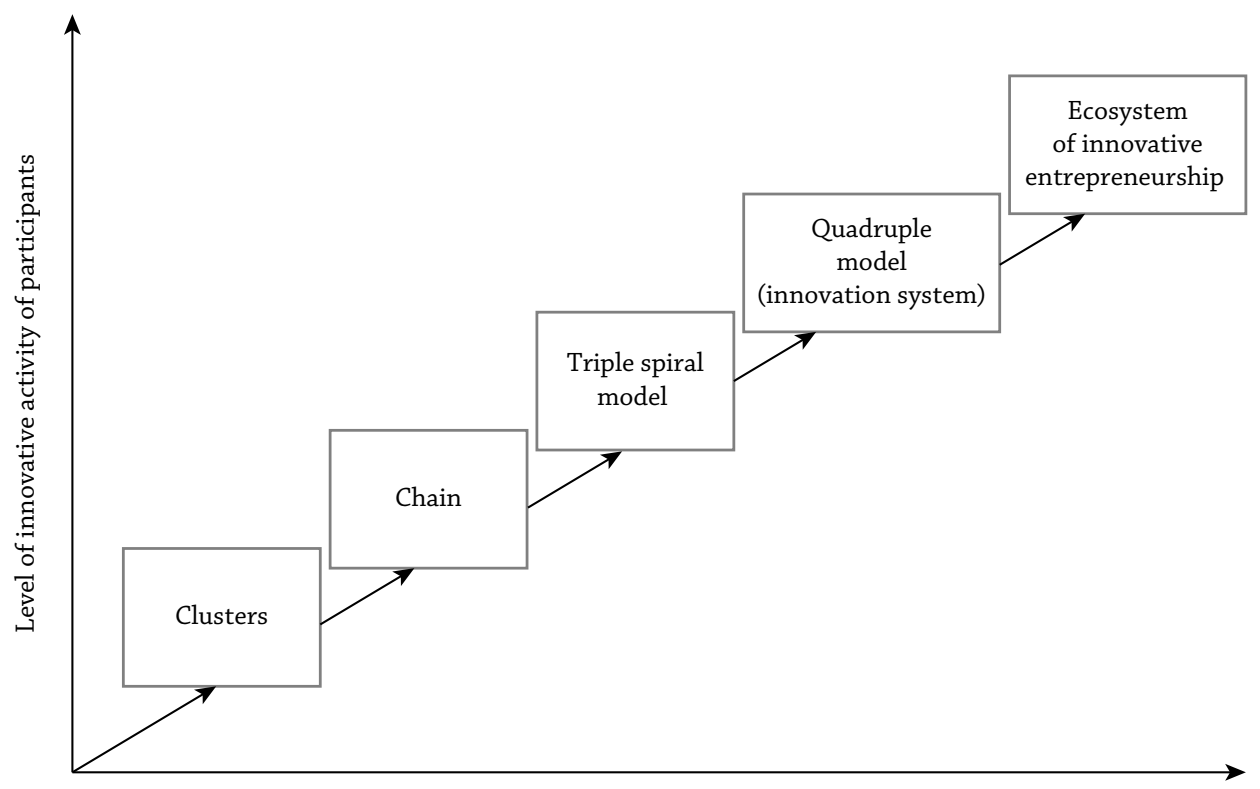

The complexity of the innovation system

Source: own work based on Helman (2020).

Analyzing Figure 4, it can be noted that interconnected companies, concentrating and merging, form clusters. With the development of clusters, networks are formed. 
Networks are alliances of companies that, as they grow, achieve a common economic goal and mutual cooperation. The development and interaction of science and business form the triple helix model. The fourfold model of innovation development is formed by universities, the industry, the government and society. The development of the innovation system when reaching the quadruple model is high. It fully meets the needs of consumers. The ecosystem of innovative entrepreneurship is formed by a network of interdependent and interconnected stakeholders such as innovative companies, business support organisations, universities, research centers, technology transfer offices, banks, venture funds, and business angels. They focus on rapid, risky, and extremely high growth.

The success of Polish entrepreneurs in the field of innovation is due to the desire to develop and implement successfully their business ideas, in close cooperation with scientists. Therefore, the experience of Poland is useful for implementation in our country.

Thus, we believe that the development of innovative entrepreneurship depends on the successful formation and development of its ecosystem. Therefore, in our opinion, for the successful development of Ukraine it is advisable to create a decentralised model of the ecosystem of innovative entrepreneurship, the main participants of which will be: state institutions, innovative firms and start-ups, corporations, venture funds, innovative entrepreneurship infrastructure, universities, NGOs, and the public (Riepina, 2018). It will be expedient to apply the bottom-up approach to the formation of the ecosystem of innovative entrepreneurship, which is based on the principle of partnership between the state and the private sector. The Ukrainian model of the ecosystem of innovative entrepreneurship is clearly shown in Figure 5.

Analysing Figure 5, we note that all the elements of the ecosystem of innovative entrepreneurship are in close interaction with each other and perform important functions:

- state institutions create the legal field, provide support and promotion of innovations on the market;

- innovative firms and start-ups create innovations;

- corporations provide investment and maintain a steady demand for innovative products;

- venture funds provide funding to innovative firms;

- infrastructure to support innovative entrepreneurship (technology parks, business incubators, business accelerators, research centres (innovation hubs), innovation park UNIT.City) provide assistance in innovation activities;

- universities provide intellectual products to the innovation market;

- non-governmental institutions and the public provide assistance in innovation activities. 
Figure 5. Ecosystem of innovative entrepreneurship of Ukraine

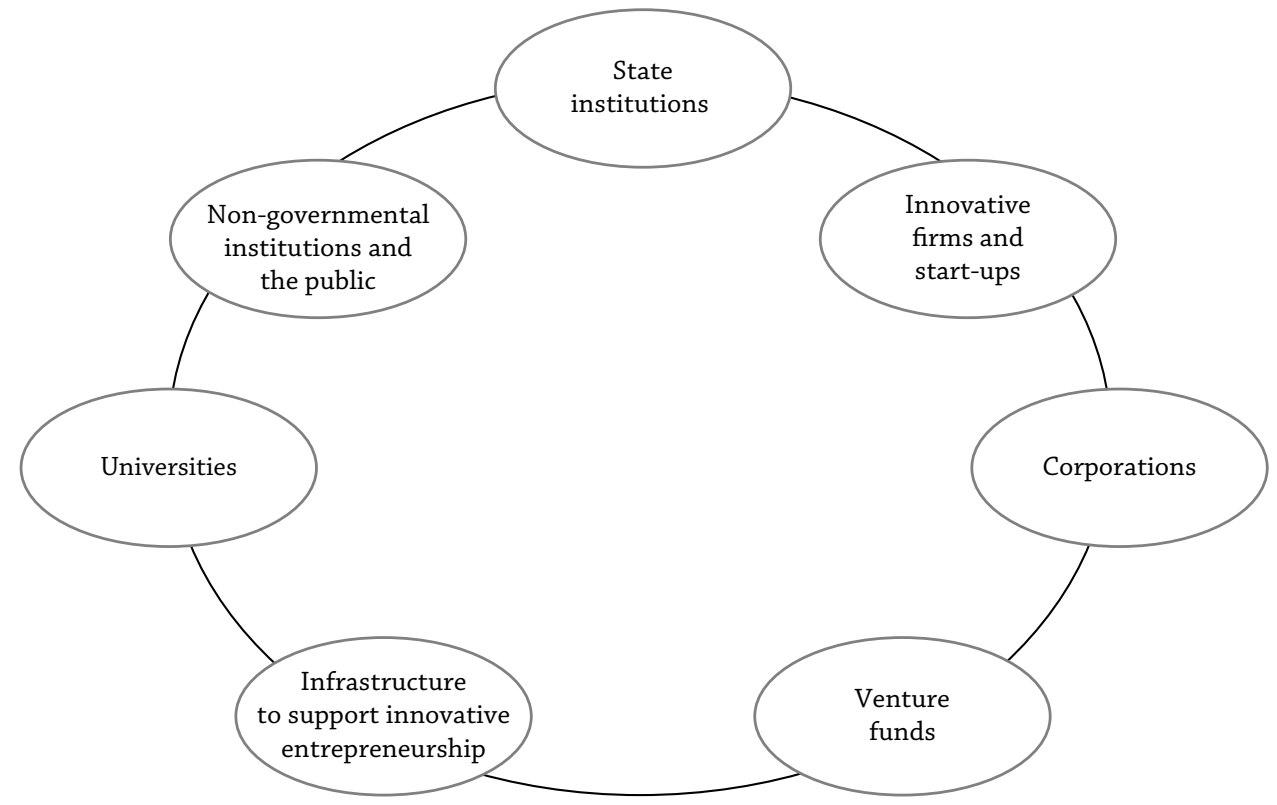

Source: own work.

The subjects of the ecosystem of innovative entrepreneurship of Ukraine must cooperate with each other following the concept of free market and partnership, which will allow for generating public goods effectively on the basis of the new nature of the ecosystem. The ecosystem of innovative entrepreneurship in Ukraine must be open and flexible, constantly changing and moving.

\section{Conclusion}

The movement of models of innovation entrepreneurship ecosystems from the triple helix to the fivefold helix model, as well as their improvement and development will help to create a highly intelligent knowledge society. Every country must move forward through the development of education and human capital, the economic system and industry, the development of the environment, the media and culture, the political system and the legislature. The development and improvement of these system components and the development of the innovation economy will ensure a country's high position in the world market. 


\section{References}

Aamna Ali Aljarwan, Bushra Alyas Yahya, Bashayer Mohamed Almarzooqi, \& Toufic Mezher (2019). Examining the framework of entrepreneurial ecosystems: A case study on the United Arab Emirates. International Journal of Entrepreneurship, 23(3). Retrieved from: https://www.abacademies.org/articles/examining-the-frameworkof-entrepreneurial-ecosystems-a-case-study-on-the-united-arab-emirates- 8555. html (accessed: 5.1.2021).

Akpinar, M., \& Qi, L. (2020). A comparison of the innovation ecosystems in China and Finland using the triple helix model. Finnish Business Review, 7, 13-26.

Barrera, A. (Ed.) (2020) A Robust Innovation Ecosystem for the Future of Europe. Report on the Results of the Stakeholder Consultation (2019-2020). European Commission, The EU Directorate-General for Research and Innovation HORIZON 2020.

König J., Suwala L., \& Delargy C. (2020). Helix Models of Innovation and Sustainable Development Goals. Econstor. Book Part - Manuscript Version (Preprint). A service of ZBW, Leibniz Information Centre for Economics. Retrieved from: https://www. econstor.eu/bitstream/10419/227112/1/K\%C3\%B6nig-Suwala-Delargy-2020-HelixModels-of-Innovation-and-SDGs-Econstor.pdf (accessed: 5.1.2021).

Millard, M. (2018). What is an innovation ecosystem and how are they essential for startups? Texas. Masschallenge. Retrieved from: https://masschallenge.org/article/startupinnovation-ecosystem-explained (accessed: 5.1.2021).

Litvinov Valery (2018) Чому в 2018 році варто розпочати інноваційний бізнес у Польщі? (Tshomu v 2018 varto rozpotshaty innovatsiiniy biznes u Polshi). Retrieved from: https://nachasi.com/2017/12/22/biznes-u-polshhi/ (accessed: 5.1.2021).

Helman, J. (2020). Analysis of the Local Innovation and Entrepreneurial System Structure Towards the "Wroclaw Innovation Ecosystem" Concept Development. Sustainability, 12, 10086.

Riepina, I. (2018). Trajectory of development of innovative entrepreneurship in Ukraine in conditions of social and technological changes. In: I. Britchebko, Ye. Polishchuk, I. Riepina et al. Development of small and medium enterprises: the EU East-partnership countries experience (pp. 186-200). Tarnobrzeg: Wydawnictwo Państwowej Wyższej Szkoły Zawodowej im. prof. Stanisława Tarnowskiego w Tarnobrzegu.

\section{Acknowledgements}

The article is prepared under the project Realization of the young scientists' potential in integration of science, education, and business (Ukrainian state registration number 0120U102126). 


\section{Inna Riepina}

Doctor of Economic Sciences (2014), PhD in Economics (1998). Currently, she holds the position of the Head of the Department of Business Economics and Entrepreneurship, Kyiv National Economic University named after Vadym Hetman, Kyiv, Ukraine. Her main directions of scientific research are formation, evaluation and management of entrepreneurial potential; asset and value management of the enterprise; innovation, intellectual property and competitiveness. During her professional activity she took an active part in many international projects associated with the Karl Duisberg Society (InWEntg GmbH: 2002), CEUME (2004), worked as a local trainer under the TACIS MTP4 programme (2006-2007). Internships in France (ESIDEC: 2004), Germany (InWEnt: 2005), Austria (UNIDO: 2009, 2016), Poland (University of Warsaw and Jagiellonian University: 20172018), Erasmus+, STAFF MOBILITY FOR TRAINING Programme (University of Foggia, Italy: 2019). She took part in the international scientific and practical conferences in Cracow, Poland (2018), Riga, Latvia (2019).

e-mail: rephousenew@gmail.com

ORCID: 0000-0001-9141-0117

\section{Nataliia Yakusheva}

PhD student at Kyiv National Economic University named after Vadym Hetman, the Department of Business Economics and Entrepreneurship, Kyiv, Ukraine. Her scientific interests are connected with the problems of development of innovative entrepreneurship and forming of its ecosystem. She has practical experience in the field of business economics; she worked at the specialist position in the SHEU company. She took part in the international scientific and practical conferences in Cracow, Poland (2018), Riga, Latvia (2019).

e-mail: nata-sheu@ukr.net

ORCID: 0000-0001-9511-2723 